\title{
RESEARCH OF THE SPECIFIC DEVELOPMENT OF THE HEALTH CARE SYSTEM IN UKRAINE
}

\author{
Serhii Makarenko', Vladyslav Danko²
}

\begin{abstract}
In modern conditions, the priority task for Ukraine is the institutional transformation of the economy, the main purpose of which is to ensure sustain-able socio-economic development. Healthcare is one of the most important elements of social infrastructure of society. Its functioning ensures the reproduction of human potential, determines the ability of the national economy as a whole in the long term to respond promptly to changes of the business environment. The purpose of the article is to identify the main trends and to predict the future development of health care in Ukraine. The methodological basis of the research consist of the scientific works of domestic, foreign scientists and leading experts, statistical and analytical materials of state authorities. A questionnaire was selected as the method of data collection for the study. The survey was conducted among the top executives of educational institutions, local authorities, Kherson trade union organizations. The results were obtained through the use of methods such as: expert method to study the impact of market factors on health; economic and mathematical methods for predicting trends in health care; abstract-logical method for theoretical generalization and formulation of conclusions. The results of the study indicate that to improve the organization of the health care system in Ukraine, it is necessary to create approaches to the development of key indicators of the system that can be applied at both national and regional levels. The governance model under development should allow to create the approaches that will give a qualitative prediction of the main indicators of health system development, primarily at the regional level, as a basis for testing and further implementation throughout Ukraine. The construction of prognostication scenarios for the development of health care for the example of the Kherson region (Ukraine) revealed the most important factors that have a significant impact on the overall outcome: the number of first reported cases of diseases in the total in the region. According to the views of the involved experts, considering the level of correlation, the following indicators are most influential: the real disposable income of the population, the economically active population aged 15-70 years, the number of hospitals, the number of doctors of all specialties and the average medical staff. It is established that in the short term the number of economically active population aged 15-70 years and the number of doctors of all specialties and medical staff have a significant impact on the number of first registered cases of diseases. Therefore, the top management of na-tional health care institutions should first and foremost ensure the development of an effective system of motivation for workers (doctors of all specialties and medical staff) to perform functional responsibilities effectively and improve the quality of medical services provided as a basis for ensuring prompt detection of cases of disease among population especially aged 15-70 years.
\end{abstract}

Key words: management, efficiency, healthcare institutions, multiple linear regression, labor resources.

JEL Classification: I11, I15, M12

\section{Introduction}

Healthcare is one of the most important elements of social infrastructure of society. Its functioning ensures the reproduction of human potential, determines the ability of the national economy as a whole in the long term to respond promptly to changes of the business environment. Also, the level of health of the country's population is an integrated indicator of quality of life and a criterion for the success of political, social and economic

\footnotetext{
Corresponding author:

${ }^{1}$ Kherson State University, Ukraine.

E-mail: makar0684@gmail.com

ORCID: http://orcid.org/0000-0001-9929-8967

ResearcherID: https://publons.com/researcher/1878529/serhii-makarenko/

${ }^{2}$ Kherson State University, Ukraine.

E-mail: vladislav1976danko@gmail.com
} 
transformations. Therefore, research of the specifics of the development of the health care system in Ukraine and the prediction of possible changes in the future is an urgent and promising area of much research.

The development of the health care system and the formation of the market of medical services in Ukraine, as well as in many other countries of the world, is based on theoretical and methodological achievements of world and national science and not only medical, but also economic, sociological, geographical, etc.

Features of formation and development of the world market of medical ser-vices were considered by such researchers as Wilson M., Glasgow R., Goldstein M., Clever A., Perkins D., Preker A. and others.

The economic aspects of the development of the health care system in Ukraine and their adaptation to global processes were carried out in their studies by such national scientists as Vorobiev E., Gaponova E., Voronenko Iu., Oliinyk N. and others. Despite the considerable experience, there remain problems that require an additional scientific analysis, especially in determining the specificity and prognostication of quantitative indicators of health care development in Ukraine.

The purpose of the article is to identify the main trends and to predict the future development of health care in Ukraine.

The methodological basis of the research consist of the scientific works of domestic, foreign scientists and leading experts, statistical and analytical materials of state authorities. A questionnaire was selected as the method of data collection for the study. The survey was conducted among the top executives of educational institutions (Medical Faculty of Kherson State University, Kherson Basic Medical College), local authorities (Kherson Regional State Administration's Department of Economic and Regional Development, State Medicines and Drug Control Service in Kherson), Kherson trade union organizations (Kherson Regional Intersectoral Council of Trade Unions). The results were obtained with methods such as: expert method to study the impact of market factors on health; economic and mathematical methods for predicting trends in health care; abstractlogical method for theoretical generalization and formulation of conclusions.

\section{Features of functioning of the health care system in Ukraine}

The current state of the health care system in Ukraine is unsatisfactory today, its capabilities and potential are being used inefficiently, and the lack of positive dynamics of the main indicators of quality of life and health of the population, despite of increasing of the industry financing, shows that the positive impact of the current health care system on public health is not only increasing but even decreasing (Makarenko, et al., 2020). The main problem of the existing national health care system is the inconsistency of the current health care model, designed to function in a planned economy, the modern needs of society and the necessary requirements for the quality of life of the population and the provision of international standards for the provision of medical services.

The conducted researches of the author (Gaponova, 2017) show that the state of development of the health care system of Ukraine in comparison with the developed countries is characterized by high rates of morbidity, mortality and disability, first of all, from noncommunicable diseases such as oncological, cardiovascular and cerebrovascular diseases, metabolic diseases and others. It should be noted that the majority of the population of Ukraine have significant risk factors for the occurrence of chronic diseases, due to bad habits, unhealthy diet, poor physical activity, environmental pollution, etc.

According to the results of 2017, the volume of the Ukrainian medical services market amounted to 80 billion UAH, which is by $20 \%$ higher than in the previous year (Vorobiev, 2017). At the same time, the conducted researches show that the amount of financing of a medical institution depends not only on the quality of the provided services, but also on its capacity. Of the current public expenditures at the hospital, about $63.5 \%$ goes to wages, $8.1 \%$ to utility bills, $16.2 \%$ to direct costs of manufacturing services and $12.2 \%$ to other expenses. In addition, a deformed structure of expenditures is being observed: up to $80 \%$ is spent on the maintenance of institutions and not on the treatment of patients.

Due to insufficient economic motivation, insufficient level of quality of the provided medical services, high mortality of newborns, low level of trust of citizens to qualified specialists are traced. 
In turn, the analysis of the level of population morbidity indicates some positive developments, since the share of cases of primary morbidity in the total population decreased by 8.01 percentage points - from $72.26 \%$ in 2010 to $64.25 \%$ in 2016 . Regarding to the structure of morbidity, prevail respiratory diseases (from 44.1 to $46.0 \%$ ), diseases of the circulatory system (from 6.7 to $7.2 \%$ ), diseases of the genitourinary system (from 6.4 to $6.5 \%)$ are preferred) and skin and subcutaneous tissue diseases (5.7\% to 5.8\%).

Due to the high mortality rate and low birth rate, the overall demographic status of Ukraine's population is significantly inferior to that of the European countries. The current state of health care is a consequence problem of infrastructure and resource providing. Thus, during 2010-2017 the total number of hospitals in Ukraine decreased by 1.1 thousand, number of outpatient clinics increased by 1.4 thousand, and number of hospital beds decreased from 94.0 thousand in 2010 to 73.1 thousand in 2017 per 10 thousand population.

In order to improve the organization of the health care system in Ukraine, it is necessary to create approaches to the development of key indicators of the system that can be applied both at the national and regional levels. The model under development should allow to create the approaches that will allow for a qualitative prediction of key indicators of health system development, primarily at the regional level, as a basis for testing and further implementation throughout Ukraine.

\section{Prognostication trends of the development of the medical services market}

In constructing prognostication scenarios, the most significant factors that influence on development of the national health care system need to be explored. Using the knowledge and experience of leading experts from educational institutions (Medical Faculty of Kherson State University, Kherson Basic Medical College), local authorities (Kherson Regional State Administration for Economic and Regional Development, State Medicines and Drug Control Service in Kherson) of trade union organizations (Kherson regional inter-branch council of trade unions), the influence of the main indicators on the number of first-time registered cases of diseases in Kherson region (Y) was investigated. According to the views of the respondents, the following indicators were found to have the greatest impact: physical volume index of gross regional product (in previous year prices), $\%\left(\mathrm{X}_{1}\right)$; real disposable income of the population, in \% compared to the corresponding period of the previous year $\left(\mathrm{X}_{2}\right)$; economically active population aged 15-70, thousand $\left(\mathrm{X}_{3}\right)$; number of hospitals, units $\left(\mathrm{X}_{4}\right)$; number of hospital beds, thousand units $\left(\mathrm{X}_{5}\right)$; number of outpatient clinics, units $\left(\mathrm{X}_{6}\right)$; capacity of outpatient clinics, visits per shift, thousand $\left(\mathrm{X}_{7}\right)$; number of doctors of all specialties, thousand people $\left(\mathrm{X}_{8}\right)$; number of average medical personnel, thousand people $\left(\mathrm{X}_{9}\right)$.

The necessary materials for further processing and determining the reliability and validity

Table 1

The necessary materials for further processing and determining the reliability and validity of building a model for the development

\begin{tabular}{|c|c|c|c|c|c|c|c|c|c|c|}
\hline \multirow{2}{*}{ Year } & \multicolumn{10}{|c|}{ Indicators } \\
\hline & $\mathrm{Y}$ & $\mathrm{X}_{1}$ & $\mathrm{X}_{2}$ & $\mathrm{X}_{3}$ & $\mathrm{X}_{4}$ & $\mathrm{X}_{5}$ & $\mathrm{X}_{6}$ & $\mathrm{X}_{7}$ & $\mathrm{X}_{8}$ & $\mathrm{X}_{9}$ \\
\hline 2004 & 725.9 & 111.2 & 121.8 & 535.1 & 74 & 12.2 & 182 & 21.4 & 4.0 & 11.9 \\
\hline 2005 & 717.2 & 99.2 & 124.1 & 548.9 & 74 & 11.8 & 181 & 21.4 & 4.1 & 11.3 \\
\hline 2006 & 696.8 & 104.0 & 109.6 & 553.0 & 74 & 11.7 & 182 & 21.5 & 4.0 & 11.2 \\
\hline 2007 & 687.5 & 100.4 & 115.9 & 551.3 & 73 & 11.5 & 187 & 21.5 & 4.0 & 11.2 \\
\hline 2008 & 686.9 & 109.8 & 104.1 & 553.6 & 71 & 11.2 & 163 & 21.6 & 3.9 & 10.3 \\
\hline 2009 & 693.7 & 93.0 & 88.2 & 538.0 & 70 & 11.2 & 167 & 20.8 & 3.9 & 10.4 \\
\hline 2010 & 693.9 & 101.8 & 118.1 & 534.9 & 71 & 11.1 & 169 & 21.5 & 3.9 & 10.4 \\
\hline 2011 & 688.0 & 103.8 & 108.1 & 528.5 & 68 & 10.9 & 165 & 20.5 & 3.9 & 10.2 \\
\hline 2012 & 675.2 & 100.2 & 111.3 & 523.4 & 63 & 10.7 & 165 & 20.6 & 3.9 & 9.8 \\
\hline 2013 & 656.5 & 101.1 & 108.9 & 524.6 & 43 & 10.0 & 226 & 20.9 & 3.9 & 9.7 \\
\hline 2014 & 594.8 & 99.7 & 85.2 & 499.8 & 43 & 9.9 & 230 & 21.4 & 3.9 & 9.7 \\
\hline 2015 & 586.8 & 98.7 & 89.2 & 496.6 & 43 & 9.7 & 230 & 21.4 & 3.9 & 9.6 \\
\hline 2016 & 577.0 & 102.8 & 102.9 & 496.9 & 40 & 8.1 & 230 & 22.3 & 3.8 & 9.0 \\
\hline 2017 & 566.0 & 100.5 & 103.7 & 497.2 & 40 & 8.0 & 233 & 24.6 & 3.8 & 8.9 \\
\hline
\end{tabular}

Source: author's construction based on Official site of the State Statistics Service of Ukraine (2020) 
building of predictive model of development are shown in table 1.

Using the formula to calculate pairwise correlation coefficients, the following relationship is established between the resultant index $(\mathrm{Y})$ and the above factors:

$-r_{y x 1}=0.26882-$ according to the scale of the relationship of variables, the relationship between $Y$ and $X_{1}$ is weak, and therefore the influence of the specified factor on the final result is insignificant and the specified indicator should not be included in the model;

$-r_{\mathrm{yx} 2}=0.625944-$ the relationship between $\mathrm{Y}$ and $\mathrm{X}_{2}$ is considered above average;

$-r_{\mathrm{yx} 3}=0.904384-$ the relationship between $\mathrm{Y}$ and $\mathrm{X}_{3}$ is considered high;

$-r_{y x 4}=0.932784-$ the relationship between $Y$ and $\mathrm{X}_{4}$ is considered high;

$-r_{y x s}=0.941622-$ the relationship between $Y$ and $\mathrm{X}_{5}$ is considered high;

$-r_{\mathrm{yx} 6}=-0.85897-$ the relationship between $\mathrm{Y}$ and $\mathrm{X}_{6}$ is considered high;

$-r_{y x}=-0.58601-$ the relationship between $Y$ and $\mathrm{X}_{7}$ is considered above average;

$-r_{y \times 8}=0.735283$ - the relationship between $\mathrm{Y}$ and $\mathrm{X}_{8}$ is considered above average;

$-r_{y x 9}=0,865572-$ the relationship between $Y$ and $\mathrm{X}_{9}$ is considered high.

Thus, the calculation of paired correlation coefficients revealed significant and insignificant factors of influence on the result indicator. Factors $\mathrm{X}_{1}$ and $\mathrm{X}_{7}$ by this criterion are not considered further and are not included to the model, which allows to simplify the calculations to some extent without significant distortions of modelling and forecasting results.

Regarding the available feedback between the total number of first reported cases of diseases $(\mathrm{Y})$ and the number of outpatient clinics $\left(\mathrm{X}_{6}\right)$, this is primarily due to changes in the structure of functioning of national healthcare institutions and the increase in the proportion of outpatient establishments, polyclinic facilities with simultaneous optimization of the number of hospitals. This is also confirmed by the close relationship between the number of hospitals $\left(\mathrm{X}_{4}\right)$ and the number of outpatient facilities $\left(\mathrm{X}_{6}\right)$ $\left(r_{x 4 \times 6}=-0.91219\right)$. Against this background, we suggest that factor $\mathrm{X}_{6}$ should not be taken into account when constructing a predictive model of health care system development in the example of Kherson region (Ukraine).
One of the conditions of expediency of using the proposed econometric model is to check the presence of multicollinearity. Using the formula to calculate pairwise correlation coefficients, there is found multicollinearity between the following indicators:

$-r_{x 3 \times 5}=0.864591$;

$-r_{\mathrm{x} 4 \times 5}=0.912896$;

$-r_{x 5 \times 9}=0.927155$

$-r_{x 8 \times 9}=0.887151$.

In view of the results obtained, we propose to further exclude factor $\mathrm{X}_{5}$ from the model. Also, given the close relationship between factors $\mathrm{X}_{8}$ and $\mathrm{X}_{9}$, we propose to use a combined indicator of the construction of the prognostication model: the number of physicians of all specialties and the average medical staff.

Therefore, we propose to use the following multiple linear regression, which predict the total number of first reported cases of diseases in the Kherson region:

$$
\mathrm{Y}=\mathrm{A}_{0}+\mathrm{A}_{1}{ }^{*} \mathrm{X}_{1}+\mathrm{A}_{2}{ }^{*} \mathrm{X}_{2}+\mathrm{A}_{3}^{*} \mathrm{X}_{3}+\mathrm{A}_{4}^{*} \mathrm{X}_{4} \text {, }
$$

where $Y$ - the total number of first reported cases of diseases, thousand;

$\mathrm{X}_{1}$ - real disposable income of the population, in \% compared to the corresponding period of the previous year;

$\mathrm{X}_{2}$ - economically active population aged 15-70, thousand;

$\mathrm{X}_{3}$ - number of hospitals, units;

$\mathrm{X}_{4}$ - number of doctors of all specialties and number of average medical personnel, thousand people.

According to the results of the calculations, the following function is obtained:

$$
\begin{aligned}
& \mathrm{Y}=7.224892+0.465461 * \mathrm{X}_{1}+0.675758 * \\
& { }^{*} \mathrm{X}_{2}+1.7959{ }^{*} \mathrm{X}_{3}+9.781189 * \mathrm{X}_{4}
\end{aligned}
$$

The results obtained are shown in Figure 1.

To determine the influence of factors $X_{1}, X_{2}$, $\mathrm{X}_{3}$ and $\mathrm{X}_{4}$ on the resultant $\mathrm{Y}$, we calculate the elasticity coefficients using the following formula:

$$
E_{y x}=A_{j} * \frac{\sum_{i=1}^{n} X_{j . i}}{\sum_{i=1}^{n} Y_{i}}
$$

where $j$-the order number of the factor;

$\mathrm{i}$ - sequence number of years;

$\mathrm{n}$-the number of years.

$\mathrm{E}_{\mathrm{yx}_{1}}=0.465461 * \frac{1491.1}{9246.2}=0.075063$

The elasticity coefficient for first factor is 0.075063, which indicates the low impact of real 


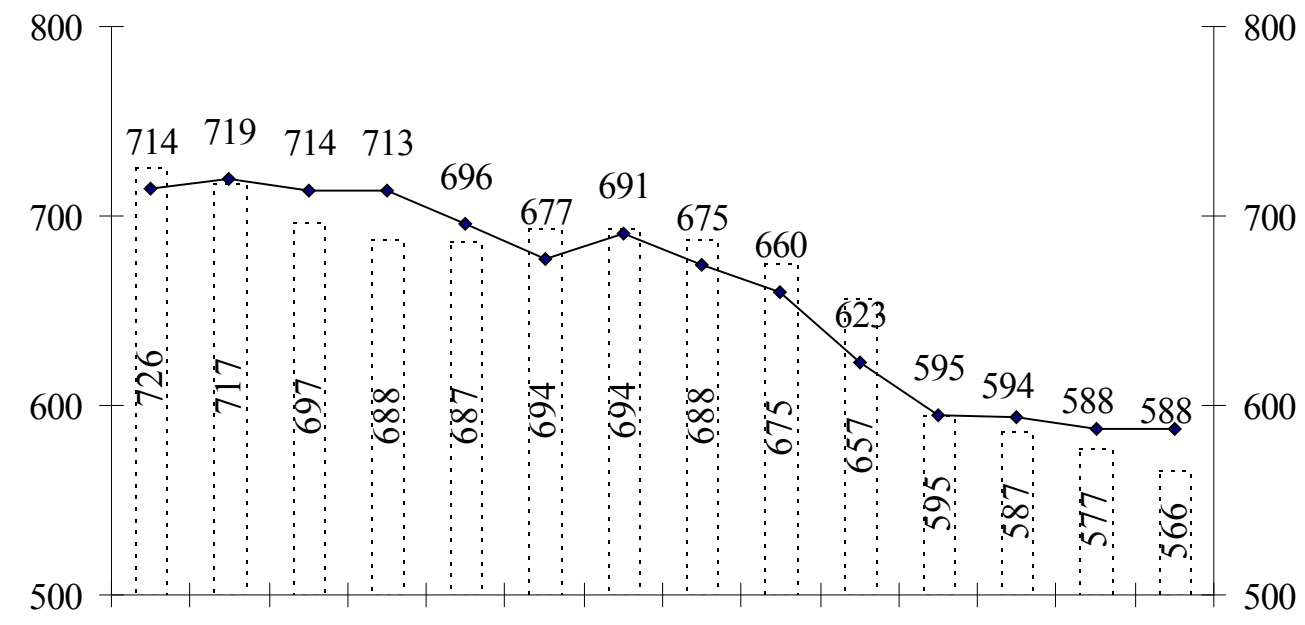

20042005200620072008200920102011201220132014201520162017

$$
\because \cdots, \mathrm{Y} \rightarrow \mathrm{Ypr}
$$

Figure 1. Construction of econometric model of the first registered cases of diseases in the Kherson region

disposable income on the number of first registered cases of diseases.

$$
\mathrm{E}_{\mathrm{yx}_{2}}=0.675758 * \frac{7381.8}{9246.2}=0.539498
$$

The elasticity coefficient for the second factor is 0.539498 , which indicates the average impact of the economically active population aged $15-70$ years on the number of first reported cases of diseases.

$$
\mathrm{E}_{\mathrm{yx}_{3}}=1.7959 * \frac{847}{9246.2}=0.164514
$$

The elasticity coefficient for the third factor is 0.164514 , which indicates a small effect on the number of hospitals on the number of cases registered for the first time.

$$
\mathrm{E}_{\mathrm{yx}_{4}}=9.781189 * \frac{198.5}{9246.2}=0.209985
$$

The elasticity coefficient for the fourth factor is 0.209985 , which indicates that the number of physicians of all specialties and the average medical staff on the number of first registered cases of diseases is insignificant.

To evaluate the level of influence of each of the factors included in the econometric model to the formation of the effective indicator - the number of first reported cases of diseases, we use the method of chain substitutions. That is, we change the numerical value of each factor of variables by $10 \%$ and compare the results obtained with the result in the last time period.
Therefore, according to the constructed economic and mathematical model, we calculate the mathematical number of first reported cases of diseases in the last time period:

$$
\begin{aligned}
& \text { Yost }=7.224892+0.465461 * 103.7+ \\
& +0.675758 * 497.2+1.7959 * 40+ \\
& +9.781189 * 12.7=587.5 \text { (thousand) }
\end{aligned}
$$

Let us increase each factor by $10 \%$ in turn:

$\mathrm{Y}_{1}=7.224892+0.465461 * 103.7 * 1.1+$

$+0.675758 * 497.2+1.7959 * 40+$

$+9.781189 * 12.7=592.4$ (thousand)

$\mathrm{Y}_{2}=7.224892+0.465461 * 103.7 * 1.1+$

$+0.675758 * 497.2 * 1.1+1.7959 * 40+$

$+9.781189 * 12.7=626.0$ (thousand)

$\mathrm{Y}_{3}=7.224892+0.465461 * 103.7^{*} 1.1+$

$+0.675758 * 497.2 * 1.1+1.7959 * 40 * 1.1+$

$+9.781189 * 12.7=633.1$ (thousand)

$\mathrm{Y}_{4}=7.224892+0.465461 * 103.7 * 1.1+$

$+0.675758 * 497.2 * 1.1+1.7959 * 40 * 1.1+$

$+9.781189^{*} 12.7 * 1.1=645.6$ (thousand)

Compare each of the following results with the previous one:

$$
\begin{aligned}
& \left.\Delta_{1}=592.4-587.5=4.9 \text { thousand }\right) \\
& \Delta_{2}=626.0-592.4=33.6 \text { (thousand) } \\
& \Delta_{3}=633.1-626.0=7.1 \text { (thousand) } \\
& \Delta_{4}=645.6-633.1=12.5 \text { (thousand) }
\end{aligned}
$$

The results of the study show that in the short term the number of economically active population aged 15-70 years and the number of doctors of all specialties and medical staff have a significant 
impact on the number of first registered cases of diseases.

Therefore, the top management of national healthcare institutions should first and foremost ensure the development of an effective system of motivation for workers (doctors of all specialties and medical staff) to effectively perform functional responsibilities and improve the quality of medical services provided as a basis for ensuring prompt detection of cases of disease among population especially aged $15-70$ years.

\section{Conclusions and recommendations for further research}

The results of the study indicate that to improve the organization of the health care system in Ukraine, it is necessary to create approaches to the development of key indicators of the system that can be applied at both national and regional levels. The governance model under development should allow to create the approaches that will give a qualitative prediction of the main indicators of health system development, primarily at the regional level, as a basis for testing and further implementation throughout Ukraine.

The construction of prognostication scenarios for the development of health care for the example of the Kherson region (Ukraine) revealed the most important factors that have a significant impact on the overall outcome: the number of first reported cases of diseases in the total in the region. According to the views of the involved experts, considering the level of correlation, the following indicators are most influential: the real disposable income of the population, the economically active population aged 15-70 years, the number of hospitals, the number of doctors of all specialties and the average medical staff.

It is established that in the short term the number of economically active population aged $15-70$ years and the number of doctors of all specialties and medical staffhave a significant impact on the number of first registered cases of diseases. Therefore, the top management of national healthcare institutions should first and foremost ensure the development of an effective system of motivation for workers (doctors of all specialties and medical staff) to perform functional responsibilities effectively and improve the quality of medical services provided as a basis for ensuring prompt detection of cases of disease among population especially aged 15-70 years.

The mechanism of determining the coefficient of competence of experts, which are involved in determining the most important factors, which influence on the development of the national health care system, taking into account their work experience, scale of management activity, level of education, deserves further study. The presented information will maximize the effectiveness of the survey and coordinate efforts and resources to improve the identified and relevant indicators for the domestic health care system.

\section{References:}

Adeyi, O., Chellaraj, G., Goldstein, E., \& Preker, A. (1997). Health status during the transition in Central and Eastern Europe: development in reverse? Health Policy Plan, pp. 132-145.

Akhlamov, A. H., \& Kusyk, N. L. (2011). Health Economics and Financing: A Learning Method. tool. Odessa.

Andreeva, Y. L. (2009). A model for optimizing the implementation of scientific results in health care practice. Volgograd Bulletin. state. honey. universities, no. 4, pp. 23-29.

Artamonova, N. O. (2009). Information support of transfer of medical technology as a modern communication mechanism of innovation activities. Bibliotekoznavstvo. Dokumentoznavstvo. Informolohiia, vol. 3, pp. 56-66.

Beliakov, V. K., Pyven, D. V., \& Antonov, D. P. (2008). On the problems of innovation policy in domestic health care and the need to create clusters of medical innovations. Management in Health, no. 3, pp. 4-11. Clever, A., \& Perkins, D. (1998). Economics for Health care Management. England, London: Prentice Hall. Financial Times.

Gaponova, E. O. (2017). Marketing approaches to the health care services market. Scientific Journal Virtus, no. 15 , pp. $247-250$.

Glasgow, R. E., Fisher, E. B., Haire-Joshu D., \& Goldstein, M. G. (2007). National Institutes of Health Science Agenda: A Public Health Perspective. AmJ Public Health, vol. 97, no. 11, pp. 1936-1938.

Hlukhovskyi, V. (2011). Community councils in the healthcare system: experiences, positions and opportunities. Upr. zakl. okhorony zdorov'ia, vol. 11, pp. 28-39. 
Karamyshev, D. V., \& Nemchenko, A. S. (2006). Implementation and evaluation of the effectiveness of innovative projects in the healthcare system. Economy and State, no. 2, pp. 86-88.

Knazevych, V. M., Lazoryshynets, V. V., Yakovenko, I. V., Slabkyi, H. O., Voronenko, Iu. V., Moskalenko, V. F., Holubchykov, M. V. and Diachuk, D. D. (2009). Healthcare Ukraine: state, problems and prospects, Kyiv. Makarenko, S., Oliinyk, N., \& Kazakova, T. (2018). Improving the method approach to the rating evaluation of employees as professional career development. Baltic Journal of Economic Studies, vol. 4, no. 5, pp. 179-187. doi: 10.30525/2256-0742/2018-4-5-179-187

Makarenko, S., Oliinyk, N., Danko, V., \& Kaplina, Y. (2020). Formation of an Innovative Competitiveness Management System of the Enterprise: On the Case of Ukraine's Healthcare. Journal of Economics and Management Sciences, vol. 3, no. 1, pp. 1-12. doi: 10.30560/jems.v3n1p1

State Statistics Service of Ukraine. Available at: http://www.ukrstat.gov.ua (accessed February 23, 2020). Tyukhtenko, N. A., \& Makarenko, S. M. (2016). Economic and mathematic models for staff planning at enterprises of all ownership forms. Actual problems of economics, no. 175, pp. 435-442.

Tyukhtenko, N., Makarenko, S., Oliinyk, N., Gluc, K., Portugal, Ed., \& Rybachok, S. (2019). Innovative development of the regions: cooperation between enterprises and state institutions. Marketing and Management of Innovations, no. 3, pp. 354-365. doi: 10.21272/mmi.2019.3-27

Vorobiev, E. M., \& Gaponova, E. O. (2017). Telemedical technologies in the global medical services market. Young Scientist, no. 7(47), pp. 413-416.

Wilson, M. E. (1995). Travel and the emergence of infectious diseases. Emerg Infect Dis. 1(2), pp. 39-46. 